\title{
Determinants of Smallholder teff Producer Farmers Market Participation in Merhabete District, Amhara Region, Ethiopia
}

\author{
Nigus Gurmis Belayneh", *, Bosena Tegegne², Alelign Ademe ${ }^{2}$ \\ ${ }^{1}$ Department of Agricultural Economics, Mizan-Tepi University, Mizan, Ethiopia \\ ${ }^{2}$ Department of Agricultural Economics, Haramaya University, Haramaya, Ethiopia \\ Email address: \\ Nigus2127g@gmail.com (N. G. Belayneh), bosenat@gmail.com (B. Tegegne), alexs2003@gmail.com (A. Ademe) \\ ${ }^{*}$ Corresponding author
}

\section{To cite this article:}

Nigus Gurmis Belayneh, Bosena Tegegne, Alelign Ademe. Determinants of Smallholder teff Producer Farmers Market Participation in Merhabete District, Amhara Region, Ethiopia. International Journal of Agricultural Economics. Vol. 4, No. 4, 2019, pp. 135-143. doi: 10.11648/j.ijae.20190404.11

Received: January 18, 2019; Accepted: April 25, 2019; Published: June 13, 2019

\begin{abstract}
Teff production contributes significantly to the economy in terms of cash income and food security, especially for the smallholder teff producers in rural areas of Ethiopia. This study examined Smallholder Teff producer Farmers Market Participation in Merhabete district with the objectives of identifying factors influencing teff market participation and intensity of participation. Cross sectional data was used for the study. A two stage sampling procedure was used to draw 150 sample producers from four teff producer kebeles and semi-structured questionnaires were used to collect data. Secondary data sources were also used for the study. Double hurdle model was used to identify factors influencing market participation decision and intensity of participation in teff market. The result of the first hurdle confirmed that participation decision was positively affected by frequency of extension contact, land allocated for teff, productivity of teff and teff production experience; whereas family size, and non-farm income influenced teff market participation decision negatively. The second hurdle indicated that intensity of teff market participation positively and significantly affected by land allocated for teff, productivity of teff, teff production experience and numbers of equine owned. The study indicated government and other stakeholders need to strengthen market oriented teff production, agricultural input or service delivery, increasing frequency of extension contacts, land intensification, family planning, and involvement in facilitating transportation services.
\end{abstract}

Keywords: Merhabete District, Double Hurdle, Market Participation, Intensity of Participation

\section{Introduction}

In Ethiopia, in $2016 / 17$ production year, the total grain production reached 290.38 million quintals $(\mathrm{Qt})$, of which cereals production accounted $87.42 \%$ [1]. Thus, cereals including teff, barley, maize, wheat and sorghum are the most important crops for Ethiopian agriculture [2]. The land productivity of these cereals is $24.84 \%$ [1].

Cereal accounts for $60,80,40$ and $60 \%$ of rural employment, total cultivated land, a typical household food expenditure and total caloric intake, respectively; its contribution to national income is also large [3]. Hence, the government gives attention to the subsector to increase production and marketing through accelerated investment in infrastructure and adoption of better seed varieties and fertilizer technology. From the demand side, cereals are the most important diets for Ethiopian families. In particular, teff, wheat, maize and sorghum are the most staple food items. The calorie intake of teff decline as one moves from lower to higher quintiles' of the wage distribution [4].

Scientifically teff is called Eragrostis tef (Zucc.) and is believed to have originated in Ethiopia [5]. It is comparatively resistant to many biotic and abiotic stresses and can be grown under different agro-ecological conditions ranging from lowland to highland areas [6].

Teff is the most important cereal in terms of both production and consumption in Ethiopia. It is witnessed that teff production increases in rapid rate in recent times. It is 
estimated that annual teff production is increasing by $11 \%$. It is believed that $6 \%$ of this production growth contribute to increased productivity while the rest was attributed to expansion in area cultivated for teff [7]. The national production and productivity of teff in 2016/17 production season in the country is 50.2 million Qt and 16.64Qt per ha, respectively [1]. Teff is produced mainly in Amhara and Oromiya region, which together accounted 84 and $86 \%$ of the total cultivated area, respectively [8].

Because of its high market price, teff accounts the largest share of the total value of cereal production and it is one of the most important crops for farm income and food security in Ethiopia [9]. Due to its farm operations such as soil planning, weeding, and harvesting, teff production is highly labor-intensive with limited availability of suitable mechanical technology. Generally, it is most important crop by area planted and value of production, and the second most important cash crop after coffee [10]. generating almost 500 million USD incomes per year for local farmers [11].

In anticipation of the 1998 war between Ethiopia and Eritrea, Eritrea was one of the major destiny markets for teff traders in major production areas. But now it is exported to different countries mainly to the Middle East, North America and to many European countries where Ethiopians or Ethiopian origin live [9].

The Amhara region teff production is 19.32 million Qt and its productivity is $16.99 \mathrm{Qt}$ per hectare [1]. North Shewa zone, one of among11 zones of Amhara region, total teff production is 2.68 million Qt. It is the second among teff producing zone of Amhara region by its teff productivity (17.80 Qt per hectare) next to east Gojam (19.23 Qt per hectare). From this, we can see that North Shewa zone is a potential area for production of teff. Based on [12], North Shewa zone is one of the most important teff producing zones in ANRS.
Merhabete district, one of the 23 districts in North Shao zone, is a high potential area for production of teff and other cereal crops. According to agricultural and natural resource office of the district, the major crops grown in the area were teff, sorghum, maize and wheat for both household consumption and marketing in 2016/17 production season. Hence this study was designed to identify teff market chain actors and their roles, analyze the structure, conduct and performance of teff market, and identify factors affecting producers' market participation decision in teff marketing and intensity of participation in the study area using data obtained from teff producers and other market participants (wholesalers, rural collectors, and retailers) in Merhabete district of North Shewa zone, ANRS, Ethiopia.

Teff is selected for this study because it is primarily grown and marketed by smallholder farmers in the study area and is produced for both consumption and marketing. Merely, the supply of teff in the study area is subjected to a seasonal variation where surplus supply at harvest is the main feature. Teff, sorghum, and wheat are the major cash crops grown in the study area predominantly for market but priori is given to teff. Therefore, there is a need to use a market chain analysis to fully understand and resolve the problem of teff markets at all levels. Nevertheless, there is no such work which attempts to await into the whole view of the marketing chain of teff in the study area. This makes a vital task of teff market chain analysis in the study district.

\section{Research Methodology}

In this chapter, study area descriptions, data types and sources, tools used to analyze collected data, model speciation test, and definition of variables and working hypothesis are presented and discussed.

\subsection{Description of the Study Area}

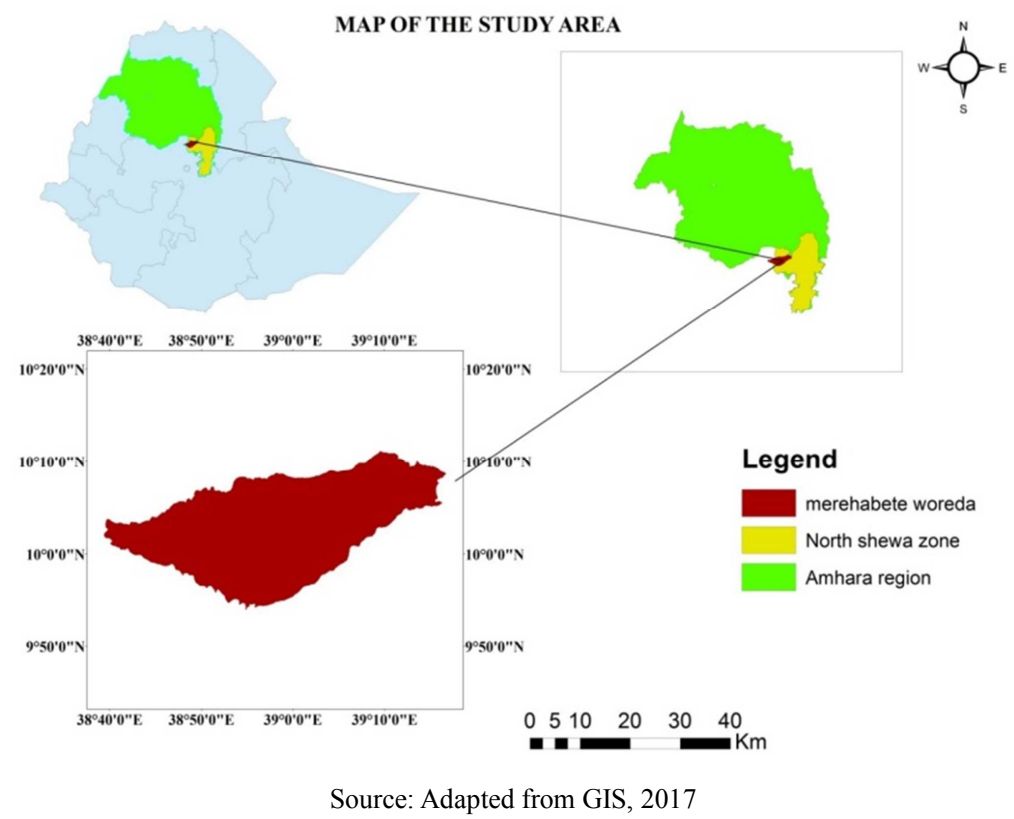

Figure 1. Geographical location of the study area. 
Merhabete district is one of the 105 districts in the Amhara region of Ethiopia. The area coverage of the district is $1,058.19 \mathrm{~km}^{2}$ and an altitude of 1911.5 meters. It is $181 \mathrm{~km}$ away from Addis Ababa (capital city of Ethiopia).

\subsection{Data Sources, Types and Methods of Data Collection}

Both primary and secondary source of data were used in this study. Primary data were collected from teff producers using a semi-structured questionnaire which is developed, modified, evaluated and pre-tested before the final data collected. Both qualitative and quantitative types of data were collected using primary source of data. A total of 8 enumerators, who are a BSc graduated students were selected, trained and employed for data collection. Secondary data sources were collected from published and unpublished documents of both qualitative and quantitative types of data.

\subsection{Sampling Technique and Sample Size Determination}

Two stage sampling technique was employed to draw a sample from teff producers. First, teff producing kebeles were identified and then four teff producer kebeles were selected randomly. Using PPS technique sample teff producers were selected from each selected sample kebeles. Finally, a total of 150 sample teff producers were randomly selected from four kebeles. The four Kebeles were Buyo-Gedejewa (44), RemeshitWorkamba (40), Amden-Lijiagba (36), and Geb-Zemoy (30).

Table 1. Number of sample respondents taken from each kebeles.

\begin{tabular}{llll}
\hline Type of grain & Name of selected kebeles & No of teff producing HHs & No of sample HHs taken \\
\hline \multirow{4}{*}{ Teff } & Buyo-Gedejewa & 458 & 44 \\
& Remeshit-Workamba & 416 & 40 \\
& Amden-Lijiagba & 375 & 36 \\
& Geb-Zemoy & 312 & 30 \\
\hline
\end{tabular}

\subsection{Methods of Data Analysis}

Both descriptive statistics and econometric model were used for data analysis.

\subsubsection{Descriptive Statistics}

Descriptive statistics like mean, standard deviation, t-test and $x^{2}$-test were used in this study.

\subsubsection{Econometric Model Specification}

Limited dependent models like Heckman two-stage models, double-hurdle model and restrictive Tobit model have been used to study crop market participation [13]. Since the mills lambda is insignificant (0.235) in this case Heckman is not appropriate for the data set of this study. Therefore, the most restrictive Tobit model and double hurdle model were compared, and finally double hurdle model found appropriate for the data set using model specification test (Tobittest $(\mathrm{LR})=2 *($ llprobit + lltruncreg-lltobit) $)$.

Among the models, the standard censored Tobit model is more appropriate than OLS estimates for corner solution outcomes that assume constant relative partial effects for a pair of explanatory variables. To overwhelm the restrictive assumptions of Tobit model, the current double-hurdle model come to be popular as explained above in the analytical methods part. This model was proposed by Cragg as an alternative to the selectivity model[14]. The first hurdle involves the decision of whether or not to sell teff whereas the second hurdle concerns the level of teff sales the producer chooses [15]. It indicates that a producer makes two decisions with respect to sale an item. Therefore, in double hurdle model, there are no restrictions regarding the elements of explanatory variables in each decision stages. The participation and quantity of teff sales equation are written as:

$$
d_{i}^{*}=X \underset{1 i}{\alpha} \alpha+\mu_{i}
$$

$d_{i}=1$ if $d_{i}^{*}>0, d_{i}=0$ otherwise

Where i represents the $\mathrm{i}^{\text {th }}$ household head, $x_{1 i}$ representing vector of factors influencing the participation decision, $\alpha$ represent vector of parameter estimates represent a random error term that is assumed to be normally distributed as $\mathrm{N}(0$, $1), d_{i} *$ representing a latent participation variable and we can observe a binary value of

$$
d i=1 \text { if } d_{i}^{*}>0, d_{i}=0 \text { if } d_{i}^{*} \leq 0, y_{i}^{*}=x_{2 i} \beta+v_{i}
$$

We observe $y i$ if: $y i=y i * i f \quad y i^{*}>0$ or $d i=1$, or $=0$ otherwise Where $y i *$ represent a latent supply variable, $x_{2 i}$ representing vectors of factors affecting the sales market decision, $\beta$ and $v i$ are error terms and assumed to have independence between them. If the two decisions made independently by individuals the error terms are assumed to be normally distributed as $\mathrm{N}(0,1)[16]$.

\begin{tabular}{|c|c|c|c|c|c|}
\hline Variables & Description & Types & Values & $\begin{array}{l}\text { Expected sign } \\
\text { participation } \\
\text { decision }\end{array}$ & $\begin{array}{l}\text { Expected sign } \\
\text { intensity of } \\
\text { participation }\end{array}$ \\
\hline TSOLD & Teff market participation & Dummy & $1=$ Yes, $0=$ No, & & \\
\hline QtTS & Quantity of teff sold & Continuous & Quintal & & \\
\hline Sex & Sex of household head & Dummy & $1=$ male, $0=$ female & + & + \\
\hline Famsza & Family size of household head & Continuous & Adult equivalent & - & - \\
\hline
\end{tabular}

Table 2. Description of variables and working hypothesis. 


\begin{tabular}{|c|c|c|c|c|c|}
\hline Variables & Description & Types & Values & $\begin{array}{l}\text { Expected sign } \\
\text { participation } \\
\text { decision }\end{array}$ & $\begin{array}{l}\text { Expected sign } \\
\text { intensity of } \\
\text { participation }\end{array}$ \\
\hline EDU & Educational status of household head & Dummy & $1=$ Literate, $0=$ Otherwise, & + & + \\
\hline TPEXP & Teff production experience & Continuous & Year & + & + \\
\hline $\mathrm{CP}$ & Current market price & Continuous & Birr & & + \\
\hline LATT & Land allocated for teff & Continuous & Hectare & + & + \\
\hline Extnc & Extension contact with agents & continuous & Frequency of extension contacts & $+/-$ & $+/-$ \\
\hline Productivity & Productivity of teff production & continuous & Quantity produced per land to teff & + & + \\
\hline INF & Income from non-farm activity & continuous & Birr & $+/-$ & $+/-$ \\
\hline QCR & Quantity of credit received & continuous & Birr & $+/-$ & $+/-$ \\
\hline PTLM & Perception about lagged market price & Dummy & $1=$ high $.0=$ otherwise & + & \\
\hline PTNM & Proximity to the nearest market & continuous & $\mathrm{Km}$ & - & - \\
\hline NEOW & Ownership of equine & Continuous & Head count & + & + \\
\hline TNOX & Ownership of oxen & continuous & Head count & + & + \\
\hline
\end{tabular}

\section{Results and Discussion}

This chapter presents the results and discussions on the core findings of the study. Thus, it is organized in to two sections. The first section provides descriptive analyses on the socio demographic characteristics of sampled households, major market chain actors and their roles, and the structure, conduct and performance of market. The second section is about econometric analysis in factors affecting teff market participation and intensity of market participation using double hurdle model.

\subsection{Descriptive Statistics}

\subsubsection{Demographic and Socioeconomic Characteristics of teff Producers}

In order to design an appropriate research and development initiative one needs to understand the basic characteristics of the decision-making unit. Descriptive statistics of the household demographic characteristics, socio-economic and institutional variables which were believed to influence decision making were assessed and the following results were obtained.

\subsubsection{Demographic Characteristics of teff Producers}

Table 5 below presents the mean differences of teff market participants and non-participants with respect to age, family size and teff production experience. The mean age of teff market participants was 67 years; while nonparticipants was 46 years. This indicates that it helps them to be participant since it increases their production and marketing experiences.

Table 3. Demographic characteristics of sample teff producers.

\begin{tabular}{llllll}
\hline \multirow{2}{*}{ Items } & \multicolumn{2}{l}{ Participants (n=90) } & \multicolumn{2}{l}{ Non-Participants (n=60) } \\
\cline { 2 - 6 } & Mean & Std. Dev. & Mean & Std. Dev. & t-value \\
\hline Age(year) & 46.91 & 14.60 & 45.60 & 13.73 & -0.58 \\
Family size(Adult equivalent) & 3.38 & 0.86 & 3.80 & 1.09 & $3.92^{* * *}$ \\
Teff production experience(year) & 25.79 & 14.18 & 20.92 & 10.45 & $2.66^{* * *}$ \\
\hline
\end{tabular}

*** Significant at $1 \%$ significance level

Source: Survey data, 2017

The mean household members in adult equivalent among participants was 3 persons, while 4 persons among nonparticipants. The two groups were statistically different on the basis of family size at $1 \%$ significance level. The mean farming experience of teff market participants was 5 years more than their counterparts, this indicates that market participants were more experienced than their counterparts in teff production. The two groups were statistically different in terms of teff production experience.

Table 4. Distribution of sample teff producers based on sex, marital and educational status.

\begin{tabular}{|c|c|c|c|c|c|c|}
\hline \multirow{2}{*}{ Variables } & & \multicolumn{2}{|c|}{ Participants $(n=90)$} & \multicolumn{2}{|c|}{ Non-participants $(n=60)$} & \multirow{2}{*}{$\chi^{2}$ value } \\
\hline & & $\mathbf{n}$ & $\%$ & $\mathbf{n}$ & $\%$ & \\
\hline \multirow[t]{2}{*}{ Sex } & Male & 82 & 59.4 & 56 & 40.6 & \multirow{2}{*}{0.241} \\
\hline & Female & 8 & 66.7 & 4 & 33.3 & \\
\hline \multirow[t]{4}{*}{ Marital status } & Single & 6 & 6.7 & 2 & 3.3 & \multirow{4}{*}{2.506} \\
\hline & Married & 71 & 78.9 & 44 & 73.3 & \\
\hline & Divorced & 6 & 6.7 & 6 & 10 & \\
\hline & Widowed & 7 & 7.8 & 8 & 13.3 & \\
\hline Educational status & Otherwise & 68 & 64 & 39 & 36 & 1.962 \\
\hline
\end{tabular}

Source: Survey result, 2017 
Tables 7 below indicate sample household resources ownership in Merhabete District. Teff market participants had 2 times of their counterparts in terms of equine owned and it exhibited statistically significant ( $1 \%$ significance level) mean differences among this groups. On the basis of land allocated to teff market participants had 1.33 ha land allocated for teff since 2016/17 production season, while nonparticipants had 1.13 ha land allocated for teff. The two groups were statistically different at 5\% significance level, implying that the more land. allocated for teff the more sample teff producers participate in the market since they expected to produce more, citrus paribus.

Table 5. Sample household resource ownership in Merhabete District.

\begin{tabular}{lllll}
\hline \multirow{2}{*}{ Variables } & \multicolumn{2}{c}{ Participant (n=90) } & & \multicolumn{2}{c}{ Non-participants (n=60) } \\
\cline { 2 - 5 } & Mean & Std. error & Mean & Std. error \\
\hline Number of equine owned & 1.8 & 1.31 & 1.13 & 0.95 \\
Number of oxen owned & 1.7 & 1.13 & 1.5 & 1.02 \\
Land owned(ha) & 1.74 & 0.89 & 1.53 & 0.87 \\
Land rented in(ha) & 0.42 & 0.54 & 0.35 & $-3.396^{* * *}$ \\
Land allocated for teff(ha) & 1.33 & 0.72 & 1.13 & -1.318 \\
Non-farm income(birr) & 1600 & 4161.89 & 2481.25 & -0.750 \\
\hline
\end{tabular}

$* * *, * *$ significant at 1,5 percent, respectively

Source: Survey result, 2017

\subsubsection{Access to Institutional Factors of teff Producers}

As indicated in table 8 below teff market participants and non-participants were statistically different at $10 \%$ significance level on the basis of access to market information. Among non-participants 55\% reported that there was no access to market information (like price information). While, among teff market participants, $64.4 \%$ reported that there was an access to market information in the study area during 2016/17 production season.

Table 6. teff Producers access to market information and perception about lagged price.

\begin{tabular}{|c|c|c|c|c|c|c|}
\hline \multirow{2}{*}{ Items } & \multicolumn{3}{|c|}{ Participant $(\mathrm{n}=90)$} & \multicolumn{2}{|c|}{ Non-participant $(n=60$} & \multirow{2}{*}{ t/ $\chi^{2}$ value } \\
\hline & & $\mathbf{N}$ & $\%$ & $\mathbf{n}$ & $\%$ & \\
\hline \multirow{2}{*}{ Access to market information } & Yes & 58 & 64.4 & 27 & 45 & \multirow{2}{*}{$5.543 *$} \\
\hline & No & 32 & 35.6 & 33 & 55 & \\
\hline \multirow[t]{2}{*}{ Perception about lagged price } & High & 25 & 27.8 & 24 & 40 & \multirow{2}{*}{2.445} \\
\hline & Otherwise & 65 & 72.2 & 36 & 60 & \\
\hline
\end{tabular}

* Significant at $10 \%$ significance level

Source: Survey result, 2017

Table 9 below illustrates about sample teff producer respondents frequency of extension contact, current market price of teff and quantity of credit utilized during 2016/17 production season in the study area. Based on this teff market participants 15 days contact extension workers per year. Teff market participants and non-participants were significantly different at $1 \%$ significant level on the basis of frequency of extension contact. Market participants were sold teff in 2016/17 teff production year with an average of 1912.64birr per qt.

Table 7. Sample teff producers'frequency of extension contact and current market price.

\begin{tabular}{|c|c|c|c|c|c|}
\hline \multirow{2}{*}{ Item } & \multicolumn{2}{|c|}{ Participants $(\mathrm{n}=90)$} & \multicolumn{3}{|c|}{ Non-participants $(n=60)$} \\
\hline & Mean & Std. Dev. & Mean & Std. Dev. & t- value \\
\hline Frequency of extension contact(days per year) & 15.54 & 6.83 & 11.38 & 5.53 & $-3.936 * * *$ \\
\hline Current market price(birr/ qt) & 1912.64 & 62.89 & -- & --- & $-2.26 * * *$ \\
\hline
\end{tabular}

$* * *$ * Significant at 1 and $10 \%$ significance level.

Source: Survey result, 2017.

\subsection{4. teff Production and Consumption by Producers}

Table 8 below predicts the production, productivity and consumption patterns of teff producers. The mean amount of teff produced by participants was $18.09 \mathrm{qt}$ per household within a year, while $9.05 \mathrm{qt}$ by non-participants per household. For the overall sample households' average amount of teff produced was $14.47 \mathrm{qt}$ per household. There was a significant difference between participants and nonparticipants in terms of amount of teff produced per household at $1 \%$ significant level. Productivity between the two groups was also significant at $1 \%$ significance level with a mean productivity of $18.9 \mathrm{qt}$ per ha of participants and 11.21qt per ha of non-participants. 
Table 8. Production, productivity, and consumption of teff among teff producers.

\begin{tabular}{llllllll}
\hline \multirow{2}{*}{ Variable } & \multicolumn{2}{l}{ Participant $(\mathbf{n}=\mathbf{9 0})$} & \multicolumn{2}{l}{ Non-participants $(\mathbf{n}=\mathbf{6 0})$} & \multicolumn{3}{l}{ Pooled sample $(\mathbf{n}=\mathbf{1 5 0})$} \\
\cline { 2 - 7 } & Mean & Std. Dev. & Mean & Std. Dev. & Mean & Std. Dev. & t-value \\
\hline Quantity of teff produced(qt) & 18.09 & 5.54 & 9.05 & 3.51 & 14.47 & 6.55 & $-11.223 * * *$ \\
Productivity(qt/ha) & 18.9 & 19.97 & 11.21 & 9.91 & 15.82 & 17.07 & $-2.763 * * *$ \\
Quantity of teff sold(qt) & 13.5 & 4.53 & 0 & 0 & 8.12 & 7.51 & $-23.082^{* * *}$ \\
\hline
\end{tabular}

***significant at 15 significance level

Source: Survey result, 2017

The mean productivity of teff in the study area were $15.82 \mathrm{qt}$ per ha for the total sample teff producers, this is lower than North Shewa Zone teff productivity, which is 18 qt per ha. Market participants and non-participants were statistically significant at $1 \%$ significance level in terms of amount of teff sold. Amount of teff sold by participants were $13.5 \mathrm{qt}$, on average. As indicated in table 8 above the average teff consumption of non-market participants was higher than participants. The two groups are statistically significant at $1 \%$ significance level.

\subsection{Econometric Model Result}

In this section factors that influence teff market participation and intensity of participation were analyzed and discussed.

Table 9. Factors influencing teff market participation and intensity of participation.

\begin{tabular}{|c|c|c|c|c|c|}
\hline \multirow{2}{*}{ Variables } & \multicolumn{3}{|c|}{ Robust } & \multicolumn{2}{|r|}{ Robust } \\
\hline & $1^{\text {st }}$ hurdle. & Std. Err. & Marginal Effects & $2^{\text {nd }}$ hurdle & Std. Err. \\
\hline Sex & -0.62 & 0.52 & -0.16 & -0.02 & 1.19 \\
\hline Family size & $-0.34 * * *$ & 0.12 & -0.12 & -0.51 & 0.55 \\
\hline Educational status(dummy) & 0.55 & 0.34 & 0.19 & -0.47 & 1.04 \\
\hline Land allotted to teff & $1.49 * * *$ & 0.35 & 0.48 & $2.59 * * *$ & 0.48 \\
\hline Extension contact(frequency) & $0.15^{*}$ & 0.09 & 0.05 & $0.54 * *$ & 0.24 \\
\hline Productivity of teff & $0.12 * * *$ & 0.03 & 0.03 & $0.14 * * *$ & 0.02 \\
\hline Non-farm income $(\log )$ & $-0.07 * *$ & 0.03 & -0.02 & -0.05 & 0.11 \\
\hline Amount of credit utilized $(\log )$ & 0.04 & 0.04 & 0.01 & 0.09 & 0.12 \\
\hline Proximity to the nearest market & -0.18 & 0.13 & -0.06 & -0.12 & 0.36 \\
\hline Equines owned(number) & -0.05 & 0.12 & -0.02 & $0.75 * *$ & 0.37 \\
\hline Oxen owned(number) & 0.03 & 1.93 & 0.01 & 0.11 & 0.40 \\
\hline Perception about lagged price (dummy) & -0.27 & 0.29 & -0.09 & & \\
\hline Current market price $(\log C P)$ & & & & 11.49 & 10.67 \\
\hline Pseudo R & 0.43 & & & & \\
\hline Predicted value & 0.75 & & & & \\
\hline Wald/LR Chi square & 45.23 & & & 60.07 & \\
\hline Log-likelihood & -57.41 & & & -243.39 & \\
\hline Observation & 150 & & & 90 & \\
\hline
\end{tabular}

$* * *, * *, *$ significant at 1,5 and $10 \%$ respectively

Source: Model output, 2017

Selection model was not appropriate for this data set since IMR is insignificant (0.235) as indicated in appendix 2[29]. Whereas, Log likelihood ratio test was used to check the relevance of the Tobit model. Then, the double-hurdle model is tested against the Tobit specification

The LR test of the double-hurdle model was tested against the Tobit model specification using joint decision criteria of $\log$ likelihood test and AIC. The test statistic for $\log$ likelihood is $(\mathrm{LR}=110.70)$ which by far exceeds the critical $\chi^{2}$ value of 23.685 at 14 degrees of freedom and at $1 \%$ level of statistical significance in favor of the double-hurdle model. Finally, double hurdle model is appropriate for this data set.

The result of double hurdle model presented in table 9 above indicates factors affecting market participation decision and intensity of participation. If it is so significant variables of both hurdle 1 (probit part) and hurdle 2 (truncated regression part) model outputs are discussed below separately.

\subsubsection{Factors Influencing teff Market Participation Decision}

The probit model performed well with a pseudo $\mathrm{R}^{2}$ of 0.43 . Out of 13 variables ( 3 dummy and 10 continuous) included in hurdle 1(probit model) 6 variables were significant. Output of double hurdle model (hurdle 1) showed that teff producers decision to participate in the teff market positively and significantly affected by land allocated to teff production, productivity of teff (qt per hectare), teff production experience and frequency of extension contact. On the other hand family size and non-farm income negatively and significantly affected the probability of teff 
producers' decision to participate in the teff market. The rest variables included in the first hurdle of this model have no effect in the participation of teff market. Under this part variables that affect teff market participation in the proposed study area are discussed.

Family size (Adult equivalent): Family size as expected had a negative and significant effect on the teff market participation decision at $1 \%$ significance level. The marginal effects of this variable indicate that an increase in adult equivalent in the family decreased the probability of teff producers' market participation by $12 \%$. This implies that most of the family members are consumers than being workers; or their contribution as a labor in teff production is less than being consumers. Increase in the family size can lead to decrease in market participation level by $3 \%$ [17]. Family size decreases the likelihood of teff market participation by $2 \%$ [10].

Land allocated to teff production: As we expected land allocated to teff production affects teff market participation positively and significantly at $1 \%$ significant level. The more land allocated to teff, the larger outputs from that land and they expected to be participated in the market. The result shown that as the land allocated to teff production increases by one hectare, the probability of teff market participation increased by As farm size increased maize and teff market participation also increased, respectively $\%$ [10-18]. The likelihood of durum wheat was positively and significantly affected by land size [28].

Productivity of teff: As hypothesized, market participation of teff positively and significantly affected by productivity of teff at $1 \%$ significance level. The marginal effect implied that, a quintal per hectare increase in the production of teff increased the probability of market participation by $3 \%$. Found that yield positively and significantly affected sesame extent of market participation in Diga district of Ethiopia [19]. Whereas, show that as land for grain crops increases yield also increased proportionately [20].

Teff production experience: The expected influence of experience in the production of teff was positive taking the presumption that as producers 'becoming more experienced in teff production they could acquire skills and hence produce Much and develop skills to participate in the market. This variable affects the likelihood of teff market participants at $5 \%$ significant level. The marginal effect showed that a one year increase in the experience of teff production increases the probability of participates in the market by $2 \%$. As farming experience of maize increases market participation of this crop increased [21].

Non-farm income: As we hypothesized non-farm income affected the probability of market participation negatively and significantly at 5\% significance level. Since they devote much of their time in non-farm activities, they did not carefully managed their farm from its preparation till harvesting (not harvested timely); it causes reduction in production. The marginal effect showed that as the income from non-farm activities increased by one birr the probability of market participation decreased by $2 \%$. As non-farm income increased by one birr maize market participation decreased by $0.035 \%$ [22];

Extension contact (frequency): As a priori to the hypothesis this variable affects teff market participation at $10 \%$ significant level. The marginal effect showed that an extra day of extension visit would increases the probability of farmers' market participation by $5 \%$. This indicates that frequent contact with extension agents improves ways of production that enhances production in turn their likelihood of market participation increased. Generally, they get up to date information on agricultural technologies like improved varieties, recommended uses of fertilizer, pesticides etc. and therefore increase market participation of teff. Frequent extension visit would increase the likelihood of red bean market participation in Alaba special district of Ethiopia [23].

\subsubsection{Factors Influencing Intensity of teff Participation}

The truncated regression model performed well and it was significant at $1 \%$ significance level. Out of 13 variables (2 dummy and 11 continuous) 4 variables were significant. The truncated regression (hurdle 2) part of double hurdle model indicate land allotted to teff production, frequency of extension contacts, productivity of teff (qt per hectare), teff production experience and number of equine owned were the most important determinants of intensity of teff participation in the market. All significant variables brought about our priori expectations and discussed below.

Land allocated for teff production: Land allocated for teff had a positive and significant effect on the intensity of teff participation at $1 \%$ significance level. As explained in the probit model result of land allotted for teff production, the more land allotted for teff results in more production and they decided to participate in the market; this in turn increases the amount of teff flow to the market, citrus paribus. The result of truncated regression model indicates that as land for teff increases by one hectare, teff supplied to the market increased by 2.6 quintal. Expanding the area under durum wheat increased the market supply. [24]. As land allotted to teff production increased market supply also increased [26]. As land allocated to maize increase market supply also increased [22].

Extension contact (frequency): Quantity of teff supplied to the market was influenced by frequency of extension contact with agents positively and significantly at 5\% significant level. With an additional extension contact increased the intensity of teff market participation by 0.54 quintal, citrus paribus. Households contact with DAs increase the intensity of market participation in the durum wheat market [24].

Productivity of teff: This variable affected intensity of teff market participation positively and significantly at $1 \%$ significant level. For this particular study as indicated in above table 9 implies as the productivity of teff increased by one qt per hectare, intensity of teff participation increased by 0.14 quintal. The total factor productivity of teff affects the volume of teff sales in the market positively [25]. Productivity of land affects intensity of teff marketed positively and significantly [27].

Equine owned (number): ownership of equine positively 
and significantly influenced the extent of teff market participation at 5\% significant level. Thus, households having one more additional equine increase the extent of producers' teff market participation by 0.75 quintal. Ownership of equines as a means of transport increased extent of red bean and teff market participation because of equines reduce marketing costs, respectively [23].

\section{Summary, Conclusions and Recommendations}

\subsection{Summary and Conclusions}

Teff is the most important cereal crop in terms of food consumption and cash formation in Ethiopia. The study was conducted in Merhabete district ANRS $181 \mathrm{~km}$ from Addis Ababa (capital city of Ethiopia) on identifying determinants of teff market participation and intensity of participation.

Data was collected from 150 households using a structured questionnaire. The sample teff producer households were drawn from four teff producer kebeles in Merhabete district. All sample households were teff producers; from these, $60 \%$ were teff market participants out of 150 producers, the rest were non-participants. Therefore, the double hurdle model was used to analyze determinants of teff market participation and intensity of participation through log likelihood ratio test.

Out of 150 total respondents, 91.1\% male headed and $8.9 \%$ female headed households were market participants, while $93.3 \%$ male headed and $6.7 \%$ female headed were nonmarket participants. The mean age of market participants was 46.91 years and 45.6 years for non-participants. The mean teff production experience of market participants was 25.79 years and 20.92 years for non-participants. The total amount of teff produced by sample teff producers was $2171 \mathrm{qt}$, of which $1215.75 \mathrm{qt}$ was supplied to the market.

Based on double hurdle model result market participation decision of teff producers was positively and significantly affected by frequency of extension contact, land allocated to teff production, teff production experience, and productivity of teff (qt/land); negatively and significantly by family size and non-farm income. Whereas, extent of teff market participation was positively and significantly influenced by land allocated to teff production, frequency of extension contact, productivity and number of equine owned. Producers' participation decision and extent of market participation jointly affected by land allocated to teff production, productivity of teff, and extension contact.

Overall econometric analysis showed a number of variables affected market participation and intensity of teff participation in the study area and all significant variables were consistent with the priori hypothesizes given.

\subsection{Recommendations}

Based on the findings of this study, the following recommendations (policy implications) are forwarded to increase market participation of producers in teff markets.
The results of econometric analysis indicate that teff producers' participation decision positively and significantly affected by teff production experience. Teff producers need to be encouraged to participate in teff production and subsequently to market participation so that new idea is injected to the system. They have to stay in teff production to increase their participation in the teff market. Teff producers need training from government related to production and market information for understanding of the business, so that their teff market participation in the market increases.

Family size negatively and significantly affected teff participation decision, indicates that most family members were consumers than being workers. Strengthening family planning programs is advisable to reduce the average family size in the long-run and they need to make their family labor productive according to the types of work they can perform in their available time, in turn their teff market participation increased. This might be done through health offices, especially by regional health offices.

Income from non-farm activities negatively and significantly affected market participation of teff. From the result it is advisable that teff producers in the study area have to spend much of their time on teff farm activities than nonfarm activities to increase their teff market participation. On the other hand, there is a need teff producers to allocate their time appropriately for non-farm income activities so as to get enough time of land for teff production, so that their teff market participation increases.

Land allocated for teff production positively and significantly affected both teff market participation and extent of market participation. It is obvious that land is the scarce but extremely important variable in the production of agricultural products. Since this variable has a positive effect, there is a need teff producers in the study area to shifting land to teff production than other crops, rent and search land lease if possible to increase their likelihood of teff participation and intensity of teff market participation to the market via increased production.

Productivity of teff positively and significantly affected both teff market participation and intensity of participation. There is a need to encourage innovations such as land use intensification policy of productivity increasing agricultural inputs (like improved teff varieties) per unit of land enables producers to produce marketable surplus of teff, so that both teff market participation and intensity of participation increases.

Extension contact affected positively and significantly both teff participation and intensity of participation. Efforts should be made to strength the linkage between research institute and district extension department so as to provide extension services on teff production and marketing. To do this employ sufficient development agents (DAs) per kebele to increase frequency of extension contact is advisable in the study. So that teff market participation and intensity of participation increase in the study area.

Numbers of equine owned affected positively and significantly intensity of teff participation. This result indicates that there needs an improvement in rural 
infrastructure like road and transport facilities-in the study area, in turn intensity of teff participation increases.

\section{References}

[1] CS A (Central Statistical Agency). (2017). Agricultural sample survey report on Area and production of major Crops (private peasant holdings, meher season 2016 / 2017); Addis Ababa Ethiopia, the FDRE statistical bulletin, Volume I.

[2] GAIN (Global Agricultural Information Network). (2014). Ethiopia grain and food manual report, Number ET1401.

[3] CSA (Central Statistical Agency). (2015). Agricultural sample survey report on Area and production of major Crops (private peasant holdings, meher season 2014 / 2015; Addis Ababa Ethiopia, the FDRE statistical bulletin, Volume I.

[4] Rashid, S. (2010). Variation in staple food prices: Causes, consequence, and policy options. Maputo, Mozambique, 2526 January 2010 under the African Agricultural Marketing Project (AAMP).

[5] Vavilov, N. I. (1951). The origin, variation, immunity and breeding of cultivated plants. Translated from the Russian by k. starrchester. Ronald press. New York. 37-38.

[6] FAO (Food and Agriculture Organization). (2015). Analysis of price incentives for teff in Ethiopia. Technical notes series, MAFAP, by Assefa B. Demeke M., Lanos B, and Rome.

[7] ATA (Agricultural Transformation Agency). (2013). Strengthening the teff value chain in Ethiopia. Ethiopian Agricultural Transformation Agency.

[8] Demeke, M. and Di Marcantonio, F. (2013). Analysis of incentives and disincentives for sorghum in Ethiopia. Technical notes series, MAFAP, FAO. Rome.

[9] Food, M. A., Policies, A., and FAO, M. (2013). Analysis of incentives and disincentives for teff in Ethiopia draft version.

[10] Efa Gobena, Degye Goshu, Tinsae Demisie and Tadesse Kenea. (2016). Determinants of market participation and intensity of marketed surplus of teff producers in Bacho and Dawo districts of Oromia State, Ethiopia. Journal of Agricultural Economics and Development, 5(2): 20-32.

[11] Minten, B. Seneshaw Tamru, Ermias Engida and Tadesse Kuma. (2013). Ethiopia's value chains on the Move: The case of teff. Ethiopian strategies support program working paper52.

[12] Yihenew Zewdie, Amdissa Teshome and Kassahun Berhanu. (2013). Drivers' of success for CAADP implementation Ethiopia, case study.

[13] Komarek, A. (2010). Determinants of banana market commercialization in Western Uganda. African Journal of Agricultural Research, 5 (9): 775-784.

[14] Cragg, J. (1971). Some statistical models for limited dependent variables with application to the demand for durable goods, Econometrica 39(1): 829-844.

[15] Newman, C., M. Henchion, and A. Matthews. (2001).
Infrequency of purchase and double-hurdle model of Irish households' meat expenditure." European review of Agricultural Economics, 28(4): 393-412.

[16] Wooldridge, J. (2002). Econometric analysis of cross-section and panel data. Massachusetts: The MIT press.

[17] Gani, B. S., and Adeoti, A. I. (2011). Analysis of Market Participation and Rural Poverty among Farmers in Northern Part of Taraba State, Nigeria, 2(1), 23-36.

[18] Martey, E., Ramatu, M. A., and John, K. M. K. (2012). Commercialization of smallholder agriculture in Ghana. African Journal of Agricultural Research, 7(14):2131-2141.

[19] Geremew Kefyalew. (2012). Analysis of smallholder farmer's participation in production and marketing of export potential crops: the case of sesame in Diga district, east Wollega Zone of Oromia regional state. MSc Thesis, Addis Ababa University, Addis Ababa, Ethiopia.

[20] Astewel Takele. (2009). Analysis of rice profitability and marketing chain: the case of Fogera woreda, South Gonder zone, Amhara national regional state. MSc Thesis Alemaya University, Alemaya, Ethiopia.

[21] Adenegan K. O., A. Adepoju and L. O. E. Nwauwa. (2012). Determinants of market participation of maize farmers in rural Osun state of Nigeria. International Journal of Agricultural Economics and Rural Development, 5(1):28-39.

[22] Beza Erko. (2014). Maize and faba bean value chains: the case of Bako Tibe and Gobu Seyo districts in central western Ethiopia. MSc Thesis, Haramaya University, Haramay, Ethiopia.

[23] Agete Jerena. (2014). Analysis of factors influencing participation of smallholder farmers in red bean marketing in Halaba special district, Ethiopia. MSc Thesis, University of Nairobi, Nairobi, Kenya.

[24] Haymanot Asfaw. (2014). Durum wheat value chain analysis: the case of Gololcha district of Bale zone. MSc Thesis, Haramaya University, Haramaya, Ethiopia.

[25] Mebrahatom Medhane. 2014). Determinants of commercialization of teff and its factor productivity outcome: the case of Tahtay Qoraro woreda, northwest zone of Tigray regional state, Ethiopia. MSc Thesis, Haramaya University Haramaya, Ethiopia.

[26] Girma Alemu. (2015). Market performance and determinants of marketed surplus of teff, in the case of Bacho woreda in south west shewa zone, Oromia national regional state. MSc Thesis, Haramaya University, Haramaya, Ethiopia.

[27] Azebe Bekele and Tadele Melaku. (2017). Determinants of smallholder farmers in teff market supply in Ambo district, West Shewa Zone of Oromia, Ethiopia. International Journal of advanced research in management and social sciences, 6(2): 133-140.

[28] Dagmawit Giref. (2016). Maize value chain analysis in south Achefer and Jabitehnan districts of ANRS. MSc Thesis, Haramaya University, Haramaya, Ethiopia.

[29] Heckman, J. J. (1979). Sample selection bias as a specification error, econometrics, 47(5): 153-161. 